\title{
Earnings Management of Firms Reporting Long Term Debt: An Alternative Method
}

\author{
Yulius Jogi Christiawan ${ }^{1 *}$, Alfa Rahmiati ${ }^{2}$ \\ ${ }^{1}$ Faculty of Economic, Petra Christian University \\ Л. Siwalankerto 121-131, Surabaya 60236 \\ ${ }^{2}$ Faculty of Economics and Business, Airlangga University \\ Jl. Airlangga 4-6, Surabaya 60286 \\ *Penulis korespondensi; email: yulius@petra.ac.id
}

\begin{abstract}
This study aims to apply an alternative detection model to prove that the earnings management will be occured when a company has long-term debts as well as the pressure of operating income. Generally, the literature study of earnings management indicates that the detection of earnings management can be grouped into two objectives, 1] to find variables for detecting earnings management (accruals, real activity and classification shifting) and 2] to use some advanced statistical or mathematical models to detect earnings management. This study applies a quantitative approach using secondary data of financial statements. The study was conducted on 50 companies with the largest market capitalization, 50 of the most active companies based on trading volume, 50 of the most active companies based on the value of trade and 50 of the most active companies by frequency trading. All of them are 200 public company (listed in the Indonesia Stock Exchange-ID) based on IDX statistical report 2013. The results of this study are expected to provide a new method to detect earnings management and its application in the context of positive accounting theory (PAT). The results of the study proves that the model is able to detect earnings management by utilizing foreign exchange transaction losses and use these models to support PAT (particularly on debt covenant hypothesis). These results contribute that earnings management can be done by using the foreign exchange gain / loss. However, the limitation of this study is the model has not been able to capture the phenomenon of earnings management if a company does not report any long-term debt nor foreign exchange gain/ loss.
\end{abstract}

Keywords: Foreign exchange loss, earnings management, positive accounting theory.

\section{INTRODUCTION}

Foreign exchange losses gives some pressures for many companies in Indonesia, particulartly to which has liabilities denominated in foreign currencies, especially when Indonesian Rupiah (IDR) current exchange rate weakened against foreign currencies. For example, based on Indonesia Central Bank data, in 2012-2013 the Indonesian Rupiah (IDR) had been depreciated $27 \%$ against the US dollar (lowest selling rate IDR 9.682 and highest selling rate IDR 12.331). Rupiah currency depreciation causes many companies which have liabilities in foreign currencies, mainly the USD, must recognize some Foreign exchange losses in their income statement. Related to the phenomenon, the objective of this study is proposing an alternative model to prove that earnings management actions will be done when the company is under pressure because of long-term debt (herein after abbreviated as LTD) and operating profit. The research questions of this study is "Do the level of long-term debt (LTD) and operating profit give impact on the earnings management actions through foreign exchange losses?"

Generally, the literature study on detection of earnings management can be classified into two kind of objective. First, researches in relation to what variables are set to detect earnings management; for example: accrual, real activity and shifting classification models. This group emphasized finding the best model to detect earnings management. Second, researches associated to the use of latest statistical or mathematical models for detecting earnings management. This group emphasize on finding best statistical or mathematical methods. These groups are not concerned 
with what appropriate kind of variables to detect earnings management. This research are expected to suggest variable used to detect earnings management.

The research question is addressed based on Positive Accounting Theory (Watt \& Zimmerman 1986). In this context, it is explained that the manager will choose a method of accounting that benefit themselves well to avoid violating covenants in debt agreements (debt contract) or for the purpose of the bonus scheme. In this study, the accounting method that increase operating profit is considered beneficial to manager.

This study applies a quantitative research approach using secondary data of financial statements of public companies listed on the Indonesia Stock Exchange (IDX). Observations are made to their audited financial statements. This research is conducted on 50 companies with the largest market capitalization, 50 of the most active companies based on trading volume, 50 of the most active companies based on the value of trade and 50 of the most active companies by frequency trading. All of them are 200 public company (listed in the Indonesia Stock Exchange) based on IDX statistical report 2013. There are three independent variables measured and analyzed in this research, namely long-term debt (LTD), operating profit and the size of the company. A regression analysis was performed to test the research hypotheses based on equation in section "Hypothesis Development" of this paper.

The regression analysis is done using SPSS 17.0 software. The alternative models is derived from long term debt (LTD), consequently this model still has its limitation; it cannot capture the phenomenon of earnings management from the profit / loss on foreign exchange if a company does not report any long-term debt nor foreign exchange losses. Thus the scope of this model is limited to companies that report long-term debt and profit / loss on foreign exchange in the financial statements. The results of this study contribute to the accounting literature, particularly the study of earnings management that earnings management can also be done by arranging the amount of profit / loss on foreign exchange.

The remaining paper will be structured as follows part two describes literatures related to some methods used for detection of earnings management and their application in the context of PAT. Part three contains the basic framework of theory and hypothesis development. Part four contains research methods, while part five lists the research findings, part six contains discussion of research findings and the last part is the conclusion and limitations.
There are three main variables to detect earnings management; i.e. accruals, real activity and shifting classification. Jones' Model (1991) is one example of an earnings management detector using an accrual basis. This model is based on an assumption that management's choice(s) of accounting policy will be reflected on its total accrual. The total accrual can be defined as the difference of cash from operating activities and the accounting profit. Total accruals are then splitted into two components; the accruals components that can not be controlled by management (normal accrual/ non-discretionary accrual) and the accruals component that can be controlled by management (abnormal accrual/discretionary accrual). The existence of earnings management can be detected from abnormal accrual/discretionary accrual. The main problem of this method is how to determine the normal value accrual/non-discretionary accrual (NDA). As the normal accrual value is known, the abnormal accruals/discretionary accruals (DA) can be calculated by subtracting the total accrual to the normal accrual/NDA.

Various researchers study earnings management detection on the basis of accruals. Jones (1991) defines NDA as a function of changes in income and fixed assets (compared to the previous period), while Dechow et al. (1995) evaluated several models that are based on statistical specification and power. Dechow et al. (1995) found that the modified Jones models have the highest statistical power than other accruals models. Becker et al. (1998) examined the effect of audit quality with earnings management. Becker, et al. (1998) measured earnings management by discretionary accruals using a model of Jones' 1991 (cross-sectional). Dechow et al. (2002) introduced a new measure for the quality of accruals and earnings. Accruals quality is measured from the residual error of regression equation for the change of working capital, operating cash flow last year, the current and next year.

Peasnell et al. (2006) investigated the relationship between outside directors and abnormal accruals. Peasnell et al. (2006) calculated an abnormal accruals as the difference between the total accrual and the normal accrual. Abnormal accruals is estimated from the normal changes of working capital for each year. Changes in working capital depend on the change in sales during the period. Next, the model is estimated for each company every year by placing the company into industry and then calculate the average relationship of all companies in the industry. Chen (2010) evaluated the Jones model application in China. Islam et al. (2011) analyzed the effectiveness of the Modified Jones Model in detecting earnings 
management. The results is similar to a research in Korea, that the Modified Jones model is not effective in detecting earnings management in Bangladesh.

Other researchers detected earnings management based on real activity. Stubben (2010) tested the ability of revenue and accrual models for detecting actual and simulated earnings management. Stubben (2010) detected the existance of earnings management by discretionary revenue. Discretionary revenue is a real activity manipulation, such as: sales discount, loosening credit terms, channel stuffing, bill and hold sales. Stubben (2010) focused on "premature" (earlier period) revenue recognition. The result showed that the revenue models produce less bias than the accrual models are commonly used. It also had better statistical specification and power than accrual models. Furthermore, by simulation procedures, it was known that the revenue model is more likely to detect a combination of revenue and expense than the manipulation of accruals models.

Eldenburg (2011) studied 432 non-profit hospital California in 1998-2003. The research used data of spending at every level of the department. Details of expenditure are used to identify the real activity of management. The analysis was done by separating between core and non-core activities. Eldenburg wanted to know whether the behavior is caused by the management of earnings management or the effectiveness of hospital operations. The result found that spendings on non-operational activities and non generating revenue activities decline, while spending on the core activity was not changed. Eldenburg also found the existence of earnings management in the non-core operating expenses. This research provides evidence on the use of real operasioanl decision to perform earnings management.

Roychowdhury (2006) detected manipulation of real activity management. Manipulation of real activity is defined as the management actions that deviate from business practices in general. The main objective is to meet certain earnings thresholds. Therefore, Roychowdhury (2006) tested the research variables; operating cash flow, production costs and discretionary expenses. Roychowdhury, S (2006) found that the company's efforts to avoid loss is done by offering price discounts to boost sales temporarily, doing overproduction to lower the cost of goods sold and lowering discretionary expenses aggressively to increase profit margins.

Earnings management can also be done by changing classification of existing accounts in the income statement (classification shifting). McVay (2006) tested the reclassification of items in the income statement as a way to make earnings management. McVay (2006) shows that the mana- gement moved (shift) expenses of core expense (COGS, G \& A expenses) to special items. This activity does not change the bottom line of the earnings, but will make the core earnings presented higher (overstated). It indicated that management uses post reclassification way to meet the expectations of the analysts' earnings targets in capital markets. The result stated that the unexpected core earnings was increasing on special items in the current year and will be reversed in the future periods. This increase will be reversed if there is no special items in the following year. This result is done only for special items that can be accepted for reclassification.

In addition, other researchers have been using several statistical methods and new mathematics methods for detecting earnings management, such as Neural Networks, decesion Trees, Bayesian Belief Network, Imperial Competitive Algorithm, Suport Vector Machine and Radial Bases Function. Hoglund (2010) tried to assess the feasibility of neural networks for detecting earnings management; particularly to separate between discretionnary acrual and non-discretionary accruals. Hoglund compared Neural Network model to linear regression models that have been used previous researchers. The conclusion showed that two of the three neural network model is able to separate properly the discretionary acrual and nondiscretionary accruals.

Kirkos et al. (2007) explored the effectiveness of the classification of data mining techniques to detect companies that commit fraud in financial reporting (fraudulent financial reporting). They compared the usefulness of three methods (i.e. Decision Trees, Neural Networks and Bayesian Belief Networks) in identifying fraud in financial reporting (fraudulent financial reporting). These three methods are compared in terms of prediction accuracy. The research conducted on the financial ratios of 76 companies manufacturing in Greece. Kirkos et al. (2007) concluded that the best results in the classification is a method of Bayesian Belief Network model with a prediction accuracy rate $90.3 \%$, followed by the method of Neural Network and Decision Tree, the accuracy rate of $80 \%$ and 73.6\%. Ezazi et al. (2013) predict earnings management using Imperial Competitive Algorithm (ICA) Support Vector Machine (SVM) and Radial Bases Function (RBF) combined with Particle Swarm Optimization (PSO). Furthermore, comparing the results of the three methods of prediction and choose the best method for predicting earnings management. The research was conducted on 113 companies listed in Tehran Security Exchange in 2005-2011. The result showed that ICA has better performance results than the other two methods. 
In the context of debt agreement covenants, many researchers used the accrual basis for detecting earnings management. Bharath et al. (2008) investigated how accounting quality affects the choice of the company in obtaining debt, public debt market (bonds) or private debt (syndicated bank), as well as how to design various debt agreements on the debt markets. Bharath et al. (2008) measured the quality of accounting by using the amount of operating accruals which is a proxy of the influence of discretionary accounting choices. The result showed that firms with worse accounting quality prefer choosing private to public debt debt. In the case of private debt, there is variation in the content of the debt agreements that are based on variations in the quality of accounting. Jaggi \& Lee (2002) found that managers of companies that experience financial stress would use income-increasing discretionary accruals if they can obtain a waiver from creditors, and use income-decreasing accruals if the debt is restructured or renegotiated because the waiver is denied. Sweeney (1994) found that managers give responses to income-increassing accounting method when a company appear to have a technical default. Meanwhile, Defond, and Jiambalvo (1994) detect the presence of income-increasing abnormal accruals one year prior to the violation of debt covenants.

This study extends those previous researches, especially on detecting earnings management. In contrast to the previous research which mostly using accrual, real activity and classification shifting as the model to detect earnings management, this study is proposing foreign exchange loss as a basis for detecting earnings management. This study will apply multiple regression analysis. Furthermore, this study will enrich the literature on earnings management, particularly related to Positive Accounting Theory implementation in conjunction with debt and shows that earnings management can be detected by this methods.

\section{Positive Accounting Theory}

According to Positive Accounting Theory (PAT) (Watts \& Zimmerman 1990), a company is considered as a collection of contracts (the nexus of contract), mainly the contracts to employees, suppliers and capital providers. If the contract involves accounting variables, and it is assumed that managers are rational, then the PAT states that the choosen accounting policies are part of the company's efforts to minimize the cost of the contract and provide the best interests of maximizing utility or manager.

The incentive to choose accounting methods include the bonus plan, the debt contract and the political cost. According to bonus plan hypothesis, managers are more likely to use accounting methods that increase the income reporting in current period. While debt contract hypothesis states firms with higher debt ratios are more likely to use accounting methods that increase income. And political cost hypothesis assumes large companies are more likely than small firms to choose accounting methods that reduced the reported profit.

\section{Hypotheses Development}

There are two hyphotheses in this research. PAT states that the selected accounting policies are part of the company's efforts to minimize the cost of the contract and provide the best interests of maximizing utility or manager. Based on this theory, the first hypothesis can be formulated as follows:

\section{H1: Long term debt influences the action of} earnings management

The sign of impact (influences) described in hypothesis 1 is expected to be negative. A high level of debt (LTD) may indicate financial stress to a company. This condition will encourage management to perform earnings management. This hypothesis is based on the "debt covenant hypothesis" of PAT. In this context, Scott (2012) explains that manager will avoid violation of covenants in debt agreements (debt contract) because it will lead to sanctions from the creditor, in the form of banning on dividends or new debt application which finally inhibit the activity of managers to do their business. Hence, earnings management can be used as a management tool to reduce the possibility of debt covenant violations. This hypothesis is supported by Jaggi \& Lee (2002), Sweeney (1994) and Defond and Jiambalvo (1994); as has been described in the literature.

H2: Operating income influences the action of earnings management (by FEL model)

The sign of impact (influences) described in hyphothesis 2 is expected to be positive. A company with low operating income will perform earnings management. Achieving an income target will be very important for management, as well as fulfilling the expectations of stock market analysts. This hypothesis is based on the "bonus plan hypothesis" of positive accounting theory (PAT). Managers with a bonus based on a net income will perform earnings management to enlarge the net income (Scott, 2012). When an operating income is very low, the manager will perform earnings management to increase net income. 
To test both hypotheses, this research proposes an equation model as follows:

$\begin{array}{ll}\text { EMFEL } i= & \beta 0+\beta 1 \text { LTD } i+\beta 2 \text { L_Opr } i+\beta 3 T A i+ \\ & \text { } i . \\ \text { Where: } & \\ \text { EMFEL }= & \text { earnings management from foreign } \\ & \text { exchange loss } \\ \text { LTD }= & \text { Long Term Debt } \\ \text { L_Opr }= & \text { Operating Income } \\ \text { TA }= & \text { Total Asset } \\ \varepsilon_{i} & \text { error term of regression equation }\end{array}$

\section{RESEARCH METHODS}

This research applies a quantitative approach; using secondary data of financial statements. This approach was chosen because the aims of this study is to prove hypotheses that earnings management actions will occur along with the expanding of long term debt (LTD) and decreasing operating income.

The unit analysis of this research are the financial statements of public companies listed on the Indonesia Stock Exchange (IDX). The research instrument is an observation which is done to each public company financial statements, to determine the amount of assets, long term debt, cash flow for repayment or from long term debt, foreign exchange losses and the amount of operating income. Data consist of statements of financial position, income statement and cash flow statement. If an income statement does not specifically states the profit/loss on foreign exchange, then the amount of profit/loss on foreign exchange will be observed in notes of the financial statements.

The population of this research was 200 public company; which consists of 50 companies with the largest market capitalization, 50 of the most active companies based on trading volume, 50 of the most active companies based on the trading value and 50 of the most active companies by frequency trading. The selection is based on statistical reports of IDX 2013. The selection of this population is conducted on the arguments that the market capitalization of the company indicates size of the company, and this variable has a significant effect on earnings management (Siregar and Utama, 2006), while the activities of public company definitely will catch many investors' attention of the market.

The sample selection is done by purposive sampling with these following criteria: a) the company is not classified in financial industry (banking \& financial institution), because the industry has different characteristics from other industries in general, b) the company uses the reporting currency of dollars, c) the company reports long-term debt (LTD) or FEL, and d) the financial statement data is completely available in IDX website 2009-2013, e) the company does not change the reporting entity. From the population (200 companies), 87 companies meet all four population criteria, 27 companies are banks and financial institutions, 13 companies use the reporting currency of USD, 18 companies do not report Long term debt or foreign exchange losses, 12 companies do not prepare completely their financial statements for the period 2009-2013 in website IDX and 1 company changes its reporting entity. Finally, there are only 42 companies match the research sample's criteria.

To test the hypotheses, this study uses the financial statements of 2012 and 2013 (42 x $2=84$ companies). The period of 2012-2013 is selected because (as mentioned earlier) during this period Indonesian Rupiah had been depreciated 27\% against the US dollar. Depreciation of the Rupiah currency also creates pressures for managers who have liabilities in foreign currencies, especially the USD, as the company must recognizes FEL.

Based on the regression equation, the variables used to test the hypothesis are earnings management actions through foreign exchange loss (EMFEL), long term debt (LTD), operating income (L_Opr) and assets (TA) of the company. The level of earning management actions by FEL model is measured by the residual errors (ct) from FEL function. FEL function can be derived; which are determined by the change long term debt (LTD), and its cash flows. Bellow is the regression equation:

$$
\text { FELt }=80+81+82 \Delta \mathrm{LTDt}+\text { B3Cash Flow LTDt }+
$$

Where:

FEL $=$ Foreign exchange loss

$\triangle \mathrm{LTD}=$ The change Long Term Debt

Cash Flow LTD = Cash flow caused by LTD

$\varepsilon i=$ error term of regression equation

All the variables are divided by average total assets to apply equal weight among companies. Residual error (ct) refers to FEL changes; which are not caused by long term debt (LTD) and its Cash Flow. It is apparently a management action (earnings management) to determine the level of FEL which subsequently impacts on earnings. The greater the residual error (ct), the greater management actions to influence the FEL in the income statement. So it can be hypothesized that the residual error (ct) FEL models simply can be used to detect the presence of earnings management. The residual error (ct) from 2012 to 2013 is 
measured as a proxy for earnings management. Then, the hypothesis was tested by applying multiple regression analysis using data 2012 to 2013. The research analysis is conducted using SPSS 17.0 software.

While long term debt (LTD) is measured by total LTD divided by the average of total assets. Total LTD is presented as long-term debt plus the matured component of LTD within a year, which are presented in a current debt. Operating income is the gross profit after deducted by operating expenses. In this study, the operating income is divided by the average of total assets. Since it is predicted that management actions are not influenced by the size of the company, this study uses a firm size (TA) as the control variable, which is measured by its total assets.

\section{RESULTS AND DISCUSSION}

The descriptive statistics for each variable of the equation is showed in Table 1.

Tabel 1. Descriptive Statistics (initial step, $n=84$ )

\begin{tabular}{lccrr}
\hline & EMFEL & LTD & L_Opr & \multicolumn{1}{c}{ TA } \\
\hline Mean & $0,00090070,2265590,1139108$ & $23.623,01$ \\
Median & $0,00006500,2184300,0937500$ & $13.208,50$ \\
Std. Deviation & $0,00678230,1532530,0918609$ & $34.827,61$ \\
Minimum & $-0,01561$ & 0,00197 & $-0,05524$ & 815,00 \\
Maximum & 0,02693 & 0,67105 & 0,53275 & $213.994,00$ \\
\hline
\end{tabular}

The results of regression test yields an equation;

$$
\begin{aligned}
\text { EMFEL }= & -0,001+0,007 L T D_{i}+0,001 L \_O p r- \\
& \text { 6,142E-9TA }
\end{aligned}
$$

However, the normality test results indicate data were not normally distributed thus this result can not be directly interpreted. To overcome the problem of normality, the removal of extreme data is required. After the removal of 15 data, the problem of classical assumptions of normality is resolved. The descriptive statistics of each variable (normalized data distribution) is presented in Table 2.

Table 2. Descriptive Statistics (Normalized step, $\mathbf{n}$ $=71)$

\begin{tabular}{lccrr}
\hline & EMFEL & LTD & L_Opr & \multicolumn{1}{c}{ TA } \\
\hline Mean & 0,0005556 & 0,2074985 & 0,1154390 & $25.103,03$ \\
Median & 0,0000800 & 0,2042800 & 0,0883000 & $12.618,00$ \\
Std. Deviation & 0,0030371 & 0,1427824 & 0,0968034 & $37.607,56$ \\
Minimum & $-0,00784$ & 0,00197 & 0,00044 & 815,00 \\
Maximum & 0,00909 & 0,67101 & 0,53275 & $213.994,00$ \\
\hline Source: Result of SPSS 17 & & &
\end{tabular}

The results of regression test in table 2 yields an equation:

$$
\begin{aligned}
\text { EMFEL }= & 0,000+0,005 L T D_{i}-6,527 E-5 L \_O p r- \\
& 3,754 E-9 T A
\end{aligned}
$$

Table 3. Result of Multiple Regression

\begin{tabular}{lrrr}
\hline & Coeficient & \multicolumn{1}{c}{ t-value } & \multicolumn{1}{c}{-value } \\
\hline Constants & 0,000 & $-0,401$ & 0,690 \\
LTD & 0,005 & 1,822 & $0,073^{*}$ \\
L_Opr & $-6,527 \mathrm{E}-5$ & $-0,016$ & 0,987 \\
TA & $-3,754 \mathrm{E}-9$ & $-0,046$ & 0,699 \\
$\mathrm{R}^{2}$ & & & $5,6 \%$ \\
F-value & & & 1,331 \\
p-value & & & 0,272 \\
\hline
\end{tabular}

Source: Result of SPSS 17, * sig 0.1, ** sig 0.05

Table 3 shows F-test and t test. By using a significance level of 0.1 , it can be concluded the variable of LTD either partially and significantly associated with EMFEL (earnings management by using FEL). The ability of the model to explain EMFEL is $5.6 \%$. means $94.6 \%$ of EMFEL is or are determined by variables other than LTD, L_Opr and TA.

To test whether managers perform such as earnings management, this research uses two hypotheses of positive accounting theory (PAT), i.e. the bonus plan hypothesis and the debt covenant hypothesis. According to bonus plan hypothesis, if the manager's performance is measured by using a net profit figure, then the manager will perform earnings management that magnify the net income. So, when the operating profit is lower, the manager will do an earnings management to increase net income, one of them by lowering the foreign exchange losses, or there is a one way relationship between the decline in operating profit to foreign exchange losses. The results of this study was not able to prove this hypothesis; the partial test results showed no significant effect ( $p$-value $>0.1$ ).

The debt covenant hypothesis explains that manager would avoid the violation of covenants in debt agreements (debt contract) because those will lead to sanctions from the creditor. So, an earnings management can be used as a management tool to reduce the possibility of violations of covenants in debt agreements. In another words, a company with high long-term debt would put pressures on manager to performs earnings management. The higher the amount of long-term debt, the higher possibility of managers to do an earnings management (to increases net income, one of them is to lower the foreign exchange losses). Or, there is a negative correlation between the magnitude of long-term debt to foreign exchange losses. The results of this study proved the existence of long- 
term debt's influence on earnings management from transactions in foreign exchange losses, which the LTD coefficient is negative and the partial test results showed a significant effect ( $p$-value $<0.1$ ).

\section{CONCLUSIONS}

To prove whether the manager did the earnings management, this research used two hypotheses of positive accounting theory (PAT); the bonus plan hypothesis and the debt covenant hypothesis. The results of the study supports one of those PAT hypotheses (debt contract hypothesis) so it is concluded that earnings management occur in the sample companies. This study implies when the reporting currency is weakened against the foreign currencies, a company with foreign currency long term debt (LTD) was in under pressure condition, therefore the model can be used as a tool for detecting earnings management in such a condition; as well as when a decreased operating income companies will be lowering foreign exchange losses in order to obtain a net income target. The results of this study contribute to the accounting literature, that management earnings management can be done from the profit/ loss on foreign exchange account.

This study has some limitations; first, the model can not capture the phenomenon of earnings management (by profit/loss on foreign exchange) if the company does not report any long-term debt and profit/loss on foreign exchange in financial statements. As in the model, foreign exchange loss is a function of the change of LTD and cash flows LTD used in financing activities, and earnings management from the residual error. Second, this model requires consistency in the use of the reporting currency

Based on those limitations, future research can be developed by improving the model of foreign exchange, proving that the model is a good model in detecting earnings management as well as incorporating other variables besides LTD and cash flows of the LTD to predict FEL, for example; monetary assets \& current monetary liability (this research uses monetary long term debt) so the model can capture much more phenomenons, broader than FEL itself (includes companies that do not report the long-term debt net income / loss on foreign exchange) and to improve the ability of the model to explain the FEL (higher $\mathrm{R}^{2}$ ).

\section{REFERENCES}

Becker, C. L., Mark, L., Defond, Jiambalvo, J., and Subramanyam, K. R. (1998). The Effect of Audit Quality on Earnings Management.
Contemporary Accounting Reserch. Spring, 15(1), pp. 1-24.

Bharath, S. T., Jayanthi, S., and Shyam, V. (2008). Accounting Quality and Debt Contracting. The Accounting Review, 82(1), pp, 1-28.

Chen, T. (2010), Analysis on Accrual-Based Models in Detecting Earnings Management. Lingnan Journal of Banking, Finance and Economics, 2, 2010/2011

Dechow, P. M., Richard, G. S., and Amy, P. S. (1995). Detecting Earnings Management, The Accounting Review, 70(2), pp. 193-225.

Dechow, P. M. \& Ilia, D. D. (2002). The Quality of Accrual dan Earnings: The Role of Accrual Estimation Errors. The Accounting Review: Supplement 2002. 77(s-1), pp. 35-59.

Defond, M. L., \& Jiambalvo, J. (1994), Debt Covenant Violation and Manipulation of Accruals. Journal of Accounting and Economics, 17, pp. 145-176.

Eldenburg, L. G., Katherine, A. G., Kevin, W. H., and Soderstrom, N. (2011). Earnings Management Using Real Activities: Evidence from Nonprofit Hospitals. The Accounting Review, 86(5), pp. 1605-1630.

Ezazi, M. E., Fatemeh, S. G., and Seyed, F. G. (2013). Predicting Earnings Management using RBF. ICA and SVM in Firm Listed in Tehran Security Exchange. Asian Journal Of Management Research, 4(1), pp. 208-220.

Hoglund, H. (2010). Detecting Earnings Management Using Neural Networks, Hanken School of Economics. Department of Accounting and Commercial Law. Vaasa, Finland.

Islam, Md. A., Ruhani, A., and Zamri, A. (2011). Is Modified Jones Model Effective in Detecting Earnings Management? Evidence from A Developing Economy. International Journal of Economics and Finance, 3(2), pp. 116-125.

Jaggi, B. \& Picheng, L. (2002), Earnings Management Response to Debt Covenant Violations and Debt Restructuring, Journal of Accounting, Auditing \& Finance, 17: 295.

Jones, J. J. (1991). Earnings Management during Import Relief Investigations. Journal of Accounting Research, 29, pp. 193-228

Kirkos, E., Charalambos, S., and Yannis, M. (2007). Data Mining Tchniques for The Detection of Fraudulent Financial Statements. Expert System with Application, 32, pp. 995-1003

Mc Vay, S. E. (2006). Earnings Management Using Classification Shifting: An Examination of Core Earnings and Special Items, The Accounting Review, 81(3), pp. 501-531.

Siregar, N. P. dan Utama, S. (2006). Pengaruh Struktur Kepemilikan, Ukuran Perusahaan 
dan Praktik Corporate Governance terhadap Pengelolaan Laba (Earnings Management). The Indonesian Journal of Accounting Research, 9(3).

Peasnell, K., Peter, P., and Steven, Y. (2006). Do Outside Directors Limit Earnings Management?. Corporate Finance Review, 10(5).

Roychowdhury, S. (2006). Earnings Management through Real Activities Manipulation, Journal of Accounting and Economics. 42, pp. 335370 .

Scott, William R. (2012). Financial Accounting Theory, $6^{\text {th }}$ edition, Pearson Prentice Hall. USA.
Stubben, S. R. (2010). Discretionary Revenues as a Measure of Earnings Management. The Accounting Review, 85(2), pp. 695-717.

Sweeney, A. P. (1994). Debt-Covenant Violations and Managers' Accounting Responses. Journal of Accounting and Economics 17, pp. 281308.

Watts, R. L. and Jerold, L. Z. (1990). Positive Accounting Theory: A Ten Year Perspective, The Accounting Review, 65(1), pp. 131-156.

www.bi.go.id/id/moneter/informasi-kurs/transaksibi/default.aspx. accessed August 2014.

www.idx.co.id, accessed September 2014. March 2015. 